cestral to that which subsequently found its way into Europe, Africa had a very distinctive ungulate fauna of its own. H. F. O.

\section{RESEARCH FUNDS OF THE SCIENTIFIC ALLIANCE OF NEW YORK.}

THE council of the Scientific Alliance of New York holds two funds, the income from which is used for the aid of investigation by persons who are members of one or more of the societies composing the alliance.

An account of the operation of these funds, up to the present time, is given herewith.

The John Strong Newberry Fund.-The plan for the administration of this fund, established as a memorial of Professor Newberry, was adopted by the council of the Scientific Alliance on February 25, 1897, and at the same time a grant of $\$ 50$ was appropriated for research in geology or paleontology. On June 14, 1897, this grant was awarded to Dr. Arthur Hollick for aid in his study of the geology and paleontology of the Atlantic Coastal Plain; during the summer of 1897 Dr. Hollick prosecuted work in New Jersey and on Long Island and Block Island with the special object of tracing the Cretaceous formation to the latter locality, where its presence had long been assumed but not proved. Dr. Hollick secured the evidence desired by the discovery of a number of species of well-known Cretaceous plants. The results of these investigations were published in the Annals of the New York Academy of Sciences, XI., 55-88, pls. II.-IX.), under the title 'Notes on Block Island,' which was subsequently reprinted as 'Contributions from the Geological Department of Columbia University, No. XLII.'

The second grant from this fund, $\$ 50$, was awarded by the council on June 22, 1898, to Mr. Gilbert Van Ingen for aid in research in paleontology. Mr. Van Ingen utilized the money in the study of the Silurian Fauna of Arkansas, and his results are published under the title "The Siluric Fauna near Batesville, Arkansas' in 'School of Mines Quarterly, XXII., 318-329 (1901), in which the geological relations are discussed, and also in the same journal, XXIII., 34-74 (1901), where the trilobites of that fauna are described.

A third grant of $\$ 50$ was awarded May 18, 1899, to Professor E. S. Burgess for aid in his studies of the genus Aster. Professor Burgess, who has been studying this difficult genus of plants with close attention for many years, is now just about completing his monograph upon them, and it will be printed in Memoirs of the Torrey Botanical Club; some of the results of this study were incorporated by him in the treatment of the genus Aster in the 'Illustrated Flora of the Northern States and Canada' by N. L. Britton and Addison Brown, also in 'Manual of the Flora of the Northern States and Canada' by N. L. Britton, and have also been used in 'The Flora of Southeastern United States' by J. K. Small.

The fourth grant from the fund, also $\$ 50$, was awarded May 17, 1900, to Dr. Marshall A. Howe, for assistance in his investigation of the algal flora of the Atlantic coast of the United States. Dr. Howe spent some time on the coast of New England and on the Bermudas, making extensive collections of the seaweeds of both regions; his studies have not yet been sufficiently advanced to enable publication to be made of them, but it is expected that some of his papers will be printed within a few months.

The fifth grant was for $\$ 100$, a friend of the alliance having added enough money to the annual interest on the fund to make up this amount, and it was authorized February 28, 1901. It was awarded to Dr. Arthur Hollick for assistance in the continuation of his studies upon the paleontology of the Atlantic Coastal Plain. Dr. Hollick's field work, by means of this grant, was carried out for the most part upon Cape Cod and Chappaquidick Island, Mass., where the furthest eastward extension of the Cretaceous formation was shown to occur, by means of the fossil plants collected, and a summary of his results under the title 'Geological and Botanical Notes: Cape Cod and Chippaquidick Island, Mass.,' is published in the Bulletin of the New York Botanical Garden, II., 381-407.

A sixth grant of $\$ 50$ was authorized May 
15, 1902, and it has been recommended by the committee on the fund, and approved by the council, that the award be made to Miss Ida M. Ogilvie, for assistance in her studies of the Strombidæ.

The Herrman Fund.-The principal of this fund amounts to $\$ 10,000$. This money was presented to the council of the alliance by Mrs. Esther Herrman in January, 1899, as a nucleus of a building fund, and with the consent of Mrs. Herman, the interest upon it is being temporarily used for the encouragement and assistance of investigation. Rules for its administration were adopted by the council in October, 1902, and the following grants have been made:

1. To Professor L. M. Underwood, of the Torrey Botanical Club, for aid in his investigations upon the ferns of tropical America, $\$ 200$. Professor Underwood is now in Jamaica and will visit Cuba and other. West Indian Islands during the next few months,

2. To Professor J. McK. Cattell, of the New York Academy of Sciences, for aid in his investigation on the natural history of American men of science, $\$ 200$.

N. L. Britton, Secretary of the Council Scientific Alliance of New York.

\section{FIFTH INTERNATIONAL CONGRESS OF APPLIED CHEMISTRY.}

I HAVE received the following communication dated December 3, 1902, from Dr. Geo. Pulvermacher, Secretary of the Fifth International Congress of Applied Chemistry to be held in Berlin, beginning May 31, 1903, with the request that it be published in SoIENCE:

The preparations for the Fifth International Congress of Applied Chemistry, which will meet in Berlin during Whitsuntide of this year and which will be the first of its kind on German soil, are advancing in a satisfactory manner. All expectations with reference to a successful session will no doubt be fulfilled to the greatest degree. The membership of the general committee and the organization committee has increased to about one hundred and fifty. We find as members of the general committee the Imperial Chancellor, all the secretaries of the various states and individual members of the same, the presidents of the Imperial Health Department, of the Patent Office as well as the Imperial Insurance Department, the ministers of the German Confederate States, almost all Prussian provincial ministers, representatives of many Prussian authorities and representatives of all German Confederate States. Furthermore, twelve members of the high courts, six members of the municipal council and common council, with the Chief Burgomaster and presiding officer of the common council at the head, and numerous representatives of various industries.

About sixty of the most prominent representatives of German science and industry compose the organization committee and are making the requisite arrangements. An extensive fund for the expenses of the Congress has been subscribed and is in the hands of the treasurer of the Congress, Deputy Doctor Böttinger.

The foreign states whose governments received notice of the Congress through diplomatic channels and who were requested to send delegates have formed separate organization committees which are in constant communication with the organization committee in Berlin. A large attendance both from European and foreign countries is expected.

The work of the congress will be done in eleven sections. The President of the congress, Professor Dr. Otto N. Witt, in conjuction with the presiding officers of the individual sections, has fixed the basic principles for the scientific arrangement of the congress. The sections have been divided as follows :

1. Analytical chemistry, apparatus and instruments; presiding officer, Professor Dr. G. von Knorre, Charlottenburg; Technische Hochschule.

2. Chemical industries of inorganic products; presiding officer, Dr. Heinecke, Berlin N. W., Wegelystr.

3. Metallurgy and explosives; presiding officer, Professor Dr. J. Weeren, Charlottenburg, Stuttgarterplatz, 13. 